\title{
World Journal of Emergency

\section{Sub capsular splenectomy for delayed spontaneous splenic rupture in a case of sickle cell anemia}

\section{Dhananjaya Sharma}

Address: Department of Surgery, Government NSCB Medical College, Jabalpur (MP) 482 003, INDIA

Email: Dhananjaya Sharma - dhanshar@gmail.com

\author{
Published: 6 May 2009 \\ Received: 19 March 2009 \\ World Journal of Emergency Surgery 2009, 4:17 doi:10.1186/1749-7922-4-17 \\ Accepted: 6 May 2009 \\ This article is available from: http://www.wjes.org/content/4/1/17 \\ (c) 2009 Sharma; licensee BioMed Central Ltd. \\ This is an Open Access article distributed under the terms of the Creative Commons Attribution License (http://creativecommons.org/licenses/by/2.0), \\ which permits unrestricted use, distribution, and reproduction in any medium, provided the original work is properly cited.
}

\begin{abstract}
Splenic ruptures are mostly due to trauma and manifest at the moment of injury with symptoms of acute intraperitoneal hemorrhage and shock. Spontaneous/pathological and delayed rupture of the spleen is not unknown. A case of delayed spontaneous splenic rupture in a case of sickle cell anemia is being reported, which was treated with sub capsular splenectomy (from within the pseudo capsule formed due to inflammation).
\end{abstract}

\section{Background}

Many pathological conditions of spleen predispose it to spontaneous rupture, diagnosis of which can be delayed due to its unusual presentation. Splenectomy is often required for splenic rupture, both for its acute and chronic presentations. Chronic splenic rupture may be associated with dense peri splenic adhesions making this surgery a difficult one. In such a scenario, avoidance of iatrogenic trauma to neighboring organs is of paramount importance. Sub capsular Splenectomy (from within the pseudo capsule formed due to inflammation) is an alternative technique and allows a safe splenectomy in cases having dense peri splenic adhesions.

\section{Case report}

KSM, a 50 year old man presented with severe pain over left hypochondrium and left lower chest wall, moderate fever on and off for one month. Pain increased on deep inspiration and radiated to left shoulder. There was no history of trauma or any disease process. On examination, only positive sign was some tenderness over left hypochondrium. Ultrasonography revealed chronic rupture of spleen with some hemoperitonem in the perisplenic area and small pleural effusion. (Figure 1) Biochemical workup did not show any abnormality, except a positive test for sickle cell trait. Patient was taken up for splenectomy because of severe pain. On exploratory laparotomy left quadrant was found cordoned off by omental adhesions. On taking down the adhesions, $250 \mathrm{ml}$ of darkish blood was drained form the area around the spleen. Dense adhesions prevented separation of spleen from diaphragm, left lobe of liver, stomach and left flexure of colon. Attempt was made to ligate splenic vessels, by opening the lesser sac, but dense adhesions prevented success of this step. Sub capsular splenectomy (SCS, from within the pseudo capsule formed due to inflammation) starting from near the diaphragm, was performed so as to avoid inadvertent iatrogenic trauma to neighboring structures. (Figure 2) Splenic vessels were identified inside the capsule and ligated by transfixing en-mass with 1-0 silk. Splenic capsule was found thickened and densely adherent to neighboring structures. (Figure 3) Abdomen was closed after a thorough lavage and a tube drain was inserted in the left sub diaphragmatic region. Removed spleen (Figure 4) was sent for histopatholgical examination. 


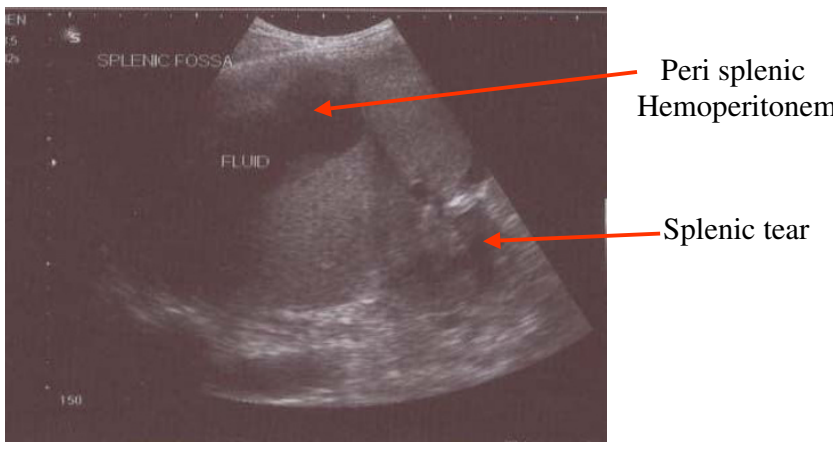

Figure I

Chronic rupture of spleen with hemoperitonem in perisplenic area.

There was $300 \mathrm{ml}$ of sero-sanguinous fluid in the drain on first post operative day, which gradually subsided and drain could be removed on fourth post operative day. Patient made an uneventful recovery.

\section{Discussion}

Causes of pathological rupture of the spleen can be classified as (1) Infections e.g., viral (infectious mononucleosis), parasitic (malaria, dengue), bacterial (abscess); (2) Congenital (cyst); (3) Metabolic (Gaucher's disease); (4) Degenerative (Amyloidosis). (5) Hematological Malignancy (leukemia, lymphoma), (6) Vascular (rupture of intrasplenic aneurysm, coagulopathy or infarct), (7) Secondary to chronic pancreatitis, and (8) Miscellaneous causes like Sickle cell disease, Peliosis, cytoreductive chemotherapy etc [1-6]. Various mechanisms of rupture of diseased spleen have been postulated: (1) Mechanical effect of distension secondary to disease infiltration of the spleen, especially the capsule; (2) Splenic infarct with capsular hemorrhage and subsequent rupture; (3) Defects in

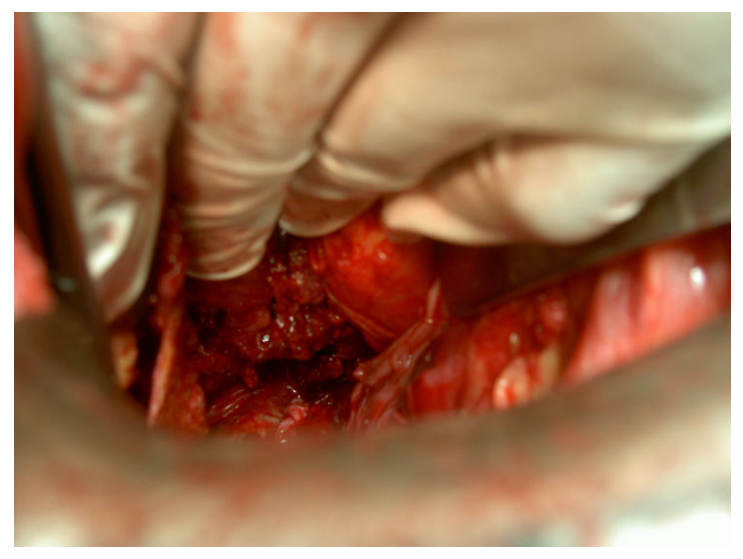

Figure 2

Sub capsular splenectomy being performed.

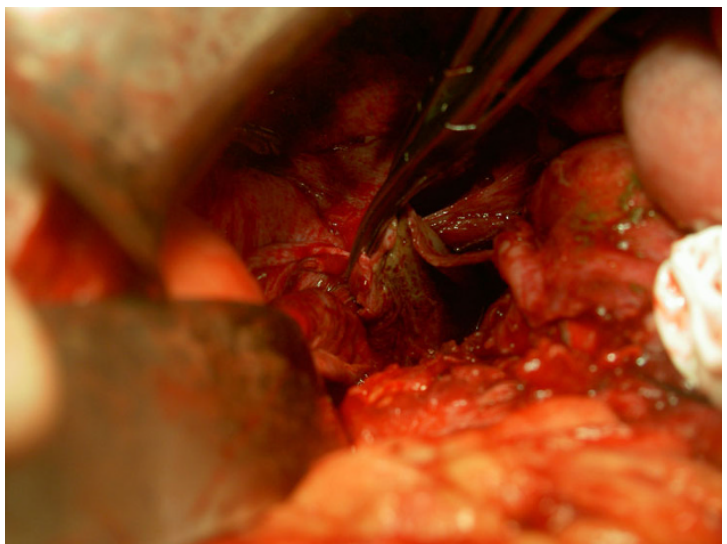

Figure 3

Thickened and densely adherent splenic capsule.

blood coagulation. Rupture probably results from a combination of these mechanisms rather than from any single mechanism [1]. In the present case there was no history of any event triggering splenic rupture, however, Sickle cell anemia is known to cause congestive splenomegaly, making it more prone to rupture [7].

Most patients thought to have delayed rupture of the spleen have, instead, delayed recognition of splenic rupture [8]. Lesser trauma resulting from minor falls or fights, often forgotten or unnoticed, is more likely to lead to delayed, so called spontaneous rupture. Subcapsular hematoma is the most common etiology for delayed splenic rupture [9]. But, Subcapsular Hematoma is neither a predictor for delayed splenic rupture, nor by itself an indication for operative management of the injured spleen in a hemodynamically stable patient [10]. Decision to operate must be taken based on imaging by ultrasonography or CT scan. The ultrasonologist was able to

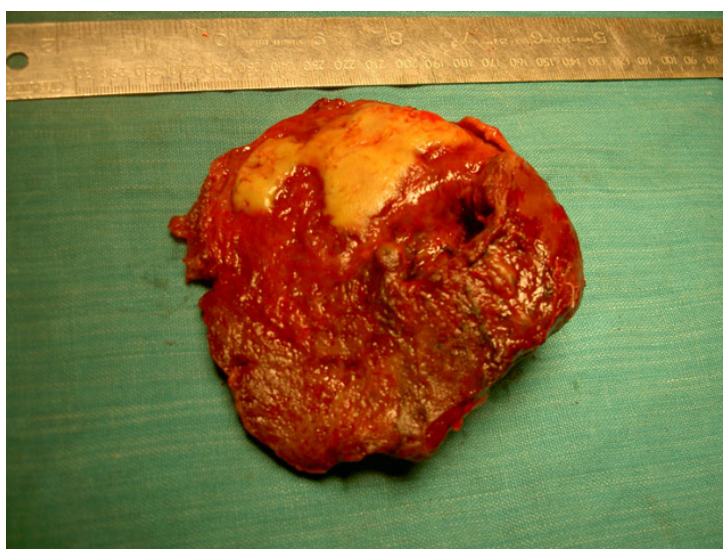

Figure 4

Removed spleen. 
diagnose chronic rupture of spleen due to the presence of 'old' blood along with splenic rupture [11]. In the present case the decision to perform Splenectomy was taken due to severe pain.

Sub capsular nephrectomy is performed in cases of pyonephrosis with non-functioning kidney as tissue planes around the kidney are lost due to infective pathology. Presence of blood around spleen for one month may have led to dense perisplenic adhesions, which prompted the performance of SCS (from within the pseudo capsule formed due to inflammation), which led to safe and successful outcome in this case.

\section{Conclusion}

Sub capsular Splenectomy (from within the pseudo capsule formed due to inflammation) is an alternative technique and allows a safe splenectomy in cases having dense peri splenic adhesions. This procedure avoids potentially dangerous attempts at removing all the dense adhesions and fibrin layer that might in some cases have formed a pseudo capsule. The knowledge of this procedure will be an additional weapon in the armamentarium of surgeons, when facing similar problem.

\section{Competing interests}

The author declares that they have no competing interests.

\section{Consent}

Written informed consent was obtained from the patient for publication of this case report and accompanying images. A copy of the written consent is available for review by the Editor-in-Chief of this journal.

\section{References}

I. Canady MR, Welling RE, Strobel SL: Splenic rupture in leukemia. J Surg Oncology I989, 4 I(3): 194-7.

2. Wang JY, Lin YF, Lin SH, Tsao TY: Hemoperitoneum due to splenic rupture in a CAPD patient with chronic myelogenous leukemia. Perit Dial Int 1998, I8(3):334-7.

3. Peña Fernández E, de la Cruz Burgos R, Del Cerro González JV, Rebollo Polo M: Spontaneous rupture of the spleen secondary to intrasplenic aneurysm. Radiologia 2007, 49(6):424-6. [Article in Spanish]

4. Malka D, Hammel P, Lévy P, Sauvanet A, Ruszniewski P, Belghiti J, Bernades $P$ : Splenic complications in chronic pancreatitis: prevalence and risk factors in a medical-surgical series of $\mathbf{5 0 0}$ patients. Br J Surg 1998, 85( I 2): 1645-9.

5. Rege JD, Kavishwar VS, Mopkar PS: Peliosis of spleen presenting as splenic rupture with haemoperitoneum - a case report. Indian J Pathol Microbiol 1998, 4I(4):465-7.

6. Goerg C, Schwerk WB: Splenic infarction: sonographic patterns, diagnosis, follow-up, and complications. Radiology 1990 , I74(3.1):803-7.

7. Gnassingbe K, Akakpo-Numado GK, Attipou K, Gbadoe A, Tekou H: Prophylactic splenectomy to prevent complications of splenomegaly in children with sickle cell anemia? Sante 2007, I7(4):207-II. [Article in French]

8. Olsen WR, Polley TZ Jr: A second look at delayed splenic rupture. Arch Surg 1977, I I 2(4):422-5.

9. Farhat GA, Abdu RA, Vanek VW: Delayed splenic rupture: real or imaginary? Am Surg 1992, 58(6):340-5.
10. Black JJ, Sinow RM, Wilson SE, Williams RA: Subcapsular hematoma as a predictor of delayed splenic rupture. Am Surg 1992, 58( ( 2):732-5.

II. Vos PM, Mathieson JR, Cooperberg PL: The Spleen. In Diagnostic Ultrasound V edition. Edited by: Rumack CM, Wilson SR, Charboneau JW. Elsevier Mosby; 2005: I47- 170.

Publish with Bio Med Central and every scientist can read your work free of charge

"BioMed Central will be the most significant development for disseminating the results of biomedical research in our lifetime. "

Sir Paul Nurse, Cancer Research UK

Your research papers will be:

- available free of charge to the entire biomedical community

- peer reviewed and published immediately upon acceptance

- cited in PubMed and archived on PubMed Central

- yours - you keep the copyright
BioMedcentral 